\title{
Miten maitotiloilla jaksetaan?
}

\author{
Marja Kallioniemi ${ }^{1}$, Hanna-Riitta Kymäläinen ${ }^{2}$, Janne Kaseva ${ }^{3}$, Ahti Simola ${ }^{4}$ \\ ${ }^{1}$ MTT Taloustutkimus, os. MTT Vihti, Vakolantie 55, 03400 Vihti, marja.kallioniemi@mtt.fi \\ ${ }^{2}$ Helsingin yliopisto, maataloustieteiden laitos, os. PL 28, 00014 Helsingin yliopisto, hanna- \\ riitta.kymalainen@helsinki.fi \\ ${ }^{3}$ MTT Kasvintuotannon tutkimus, os. Planta,31600 Jokioinen, janne.kaseva@mtt.fi \\ ${ }^{4}$ Työterveyslaitos, os. Työyhteisöt ja organisaatiot, PL 486, 33101 Tampere, ahti.simola@ttl.fi
}

\section{Tiivistelmä}

Tutkimushankkeessa Maitotilan Hyvä Vointi eli "Maidontuottajien työhyvinvointi keinona edistää eläinten hyvinvointia ja yrittäjien jaksamisen tukeminen muutoksessa" selvitettiin vuosina 2009-2011, miten maitotiloilla jaksetaan. Hankkeen toteuttivat Helsingin ja Itä-Suomen yliopistot, MTT (Maa- ja elintarviketalouden tutkimuskeskus), Työterveyslaitos ja Novetos Oy sekä rahoittivat MMM (Makera), Maatalousyrittäjien eläkelaitos Mela ja MTT.

Vuoden 2010 keväällä toteutettuun postikyselyyn saatiin vastaukset 265 maidontuottajalta. Kysely lähetettiin maaseutuelinkeinohallinnon rekisteristä satunnaisesti poimituille maitotiloille $(n=400)$ ja analyysikelpoisia lomakkeita saatiin $47 \%$ :lta otoksen maitotiloista.

Keskimäärin merkittävimmiksi voimavaratekijöiksi arvioitiin "Lapsi tai lapset", "Oma perhe", "Eläinten terveys" ja "Oma puoliso tai kumppani". Maidontuottajien voimavarojen keskeisimmät lähteet ovat siis omassa lähipiirissä, mukaan lukien navetan terveet hoidokit. Keskimäärin vähiten merkittäviksi voimavaratekijöiksi jäivät "Luottamustehtävät", "Uskonto" ja "Viljelijöiden vertaistuki".

Kuormitustekijöistä merkityksellisimmiksi arvioitiin "EU:n maatalouspolitiikka", "Viljelijöiden kohtelu yhteiskunnassa ja mediassa" ja "Maatalousalan tulevaisuus". Vastaajia keskimäärin vähiten kuormittaviksi tekijöiksi jäivät "Oma tai muun henkilön alkoholin tai päihteiden käyttö", "Kumppani puuttuu" sekä "Suhteet vanhempiin tai appivanhempiin".

Kyselyyn sisältyi työuupumuksen arviointimittari. Vastaajista miltei puolella (46\%:lla) ei ollut lainkaan työuupumusta, samoin miltei puolella (45\%:1la) oli lievää työuupumusta ja $9 \%$ vastaajista poti vakavaa työuupumusta. Kun tuloksia verrataan Jari Hakasen (2005) 44-57 -vuotiaista suomalaisista $(n=532)$ esittämiin tuloksiin, havaitaan, että maidontuottajat olivat tilastollisesti merkitsevästi useammin uupuneen väsyneitä ja kyynisiä kuin vertailuaineiston vastaajat keskimäärin. Ammatilliseen itsetuntoon liittyvien vastausten osalta aineistot eivät eroa toisistaan. Kahden tutkimuksen otokset kuitenkin erosivat toisistaan ainakin ikä- ja sukupuolirakenteeltaan.

Työn imu -mittarin tuloksia verrattiin Hakasen (2009) esittämään suomalaisista työntekijöistä $(n=16335)$ koostuvaan aineistoon. Vastaajien keskimääräiset lukuarvot eivät eronneet toisistaan tilastollisesti merkitsevästi kahdessa aineistossa. Kun tarkasteltiin erikseen työn imun kolmea ulottuvuutta, lypsykarjatilallisten havaittiin kokevan tilastollisesti merkitsevästi enemmän työhön uppoutumista ja sille omistautumista kuin suomalaisista työntekijöistä koostuvassa verranneaineistossa. Vertailussa on jälleen otettava huomioon, että otokset erosivat toisistaan.

Tulokset kertovat maidontuottajien positiivisesta työhön uppoutumisesta ja työlle omistautumisesta. Kuitenkin yli puolet (54 \%) vastaajista poti jonkinasteista työuupumusta. Työuupumuksen mittari osoitti, että joka kymmenes (9\%) kyselyyn vastannut maidontuottaja sijoittui ryhmään "vakava työuupuminen".

\section{Lähteet:}

Hakanen, J. 2005. Työuupumuksesta työn imuun: työhyvinvointitutkimuksen ytimessä ja reunaalueilla. Työ ja ihminen, tutkimusraportti 27. Väitöskirja. Helsinki: Työterveyslaitos.

Hakanen J. 2009. Työn imun arviointimenetelmä. Helsinki: Työterveyslaitos

Asiasanat: jaksaminen, maatila, maidontuotanto, työhyvinvointi, työn imu, työuupumus 


\section{Johdanto}

Maaseudun elinympäristö saatetaan yhdistää työhyvinvoinnin osalta positiivisiin ominaisuuksiin kuten rauhallisuuteen, seesteisyyteen ja kiireettömyyteen. Norjalainen tutkija Kjersti Melberg (2003) toteaakin kokoavasti norjalaisten maatalousyrittäjien työhyvinvointia selvittäneessä tutkimuksessaan, että maatalouden elämäntyyli lisää hyvinvointia ja viljelijät hallitsevat erityisen hyvin elämäänsä. Norjalaiset viljelijät arvostavat hyvinvointiaan lisäävinä tekijöinä vapautta, riippumattomuutta, eläinten parissa työskentelyä sekä työympäristön ilman raikkautta.

Suomalaisen maatalouden toimintaympäristöä ei voida kuitenkaan luonnehtia seesteiseksi. Viime vuosina maatalous- ja elintarviketalouden markkinat ovat globalisoituneet aiheuttaen tuotteiden ja tarvikkeiden hintavaihteluita (Rikkonen, 2011). Myös ilmastonmuutokseen viittaavia ilmiöitä on koettu kasvukauden aikana Suomessakin. Kuluneina vuosikymmeninä maatalouden rakennemuutos on edennyt, mutta erityisesti EU-jäsenyyden jälkeisenä ajanjaksona muutokset tilamäärässä ja jatkavien tilojen koossa ovat olleet huomattavia. Vuosina 1995-2010 maatilojen määrä on laskenut runsaalla kolmanneksella (35\%) ja maatilojen keskimääräinen peltoala on kasvanut yli puolella (60 \%) (Väre, 2011). Tällainen yhden työalan muutoskehitys on ollut määrällisesti tarkastellen ainutlaatuinen ilmiö suomalaisessa yhteiskunnassa, mutta myös Euroopan laajuisesti vertaillen (Enroth ym., 2003). Maataloustuotanto perustuu Suomessa kuitenkin edelleen perheviljelmiin, sillä $88 \%$ tiloista on yksityishenkilöiden omistuksessa, perikunnat, perheyhtiöt ja -yhtymät omistavat $10 \%$ ja loput maatilat ovat yritysmuotoisia tai julkisyhteisöjen omistuksessa (Väre, 2011).

Aiemmat tutkimustulokset maatalousyrittäjien työhyvinvoinnista eivät ole olleet positiivista luettavaa. Useissa suomalaisissa tutkimuksissa (Peltoniemi, 2005; Saarni ym., 2008 ja Martelin ym., 2010) on verrattu palkansaajien, maatalousyrittäjien ja muiden yrittäjien työkykyä yhtenevin tuloksin: maatalousyrittäjien työkyky on ollut alhaisimmalla tasolla kahteen muuhun ryhmään verrattuna.

Työterveyslaitoksen vuonna 2004 toteuttamassa laajassa puhelinhaastattelututkimuksessa (vastaajina 1182 päätoimista maatalousyrittäjää) ilmeni, että neljännes (26\%) haastatelluista koki voimattomuutta ja väsymystä. Kyseisten oireiden tuntemukset olivat tilastollisesti merkitsevästi lisääntyneet edelliseen seurantatutkimukseen vuodelta 1992 verrattuna (Kallioniemi ym., 2009). Miltei joka viides (19 \%) päätoimisista maatalousyrittäjistä oli kokenut unettomuutta tai vaikeuksia nukahtaa, ja myös tämä oire oli tilastollisesti merkitsevästi lisääntynyt vuoden 1992 tutkimukseen verrattuna (Kallioniemi ym. 2009). Tulosten on tulkittu kertovan työuupumisen oireista. Saman haastattelututkimuksen mukaan joka kolmas vastaaja (34 \%) oli kokenut stressiä, jota koettiin maatalousyrittäjien keskuudessa kuitenkin vähemmän kuin suomalaisen työikäisen väestön haastattelututkimuksessa (Kallioniemi ym. 2008, Simola, 2006). Sen sijaan neljännessä Euroopan laajuisessa työolosuhdetutkimuksessa (Parent-Thirion ym., 2007) ilmeni, että maatalous- ja kalastuselinkeinon parissa työskentelevien keskuudessa esiintyi eniten (32\%) terveydentilaan vaikuttavaa stressiä verrattuna muihin työaloihin. Edelliseen seurantatutkimukseen vuodelta 2000 verrattuna stressin kokeminen oli vastaavassa eurooppalaisia työoloja selvittäneessä tutkimuksessa lisääntynyt eniten juuri maatalous- ja kalastuselinkeinoa harjoittavien keskuudessa. Keskimäärin stressiä koki (Parent-Thirion ym., 2007) $23 \%$ miehistä ja 21 $\%$ naisista.

\section{Aineisto ja menetelmät}

Tutkimushankkeessa Maitotilan Hyvä Vointi eli "Maidontuottajien työhyvinvointi keinona edistää eläinten hyvinvointia ja yrittäjien jaksamisen tukeminen muutoksessa" selvitettiin vuosina 2009-2011, miten maitotiloilla jaksetaan. Hankkeen toteuttivat Helsingin ja Itä-Suomen yliopistot, Maa- ja elintarviketalouden tutkimuskeskus MTT, Työterveyslaitos ja Novetos Oy. Hanketta rahoittivat MMM (Makera), Maatalousyrittäjien eläkelaitos Mela ja Maa- ja elintarviketalouden tutkimuskeskus MTT.

Vuoden 2010 tammikuun ja huhtikuun välisenä ajanjaksona toteutettuun postikyselyyn saatiin vastaukset 265 maidontuottajalta. Kysely lähetettiin maaseutuelinkeinohallinnon rekisteristä satunnaisesti poimituille maitotiloille $(n=400)$ ja analyysikelpoisia lomakkeita saatiin $47 \%$ :lta otoksen tilasta. Kyselylomakkeita postitettiin kahdessa erässä ja lisäksi vastaamattomille tiloille lähetettiin muistutuskortti. Kyselylomake oli 11 A4-liuskan pituinen. Lomake testattiin etukäteen neljällä maatalousyrittäjällä. 
Vastaajat arvioivat yhteensä 26 voimavaratekijän merkityksellisyyttä (skaala 1-7) taulukon avulla. Samaan tapaan arvioitiin 18 kuormitustekijän merkitsevyyttä. Taulukoissa luetellut voimavara- ja kuormitustekijät ideoitiin tutkimusryhmässä.

Kyselylomake sisälsi työuupumisen mittarin "Maslachin yleinen työuupumuksen arviointimenetelmä MBI-GS" (Kalimo ym, 2006), jossa vastaajaa pyydetään arvioimaan 16 omaan hyvinvointiin liittyvää väittämää. Kyselylomake sisälsi myös työn imu -mittarin "Utrecht Work Engagement Scale" (Hakanen, 2009), jossa vastaaja arvioi samaan tapaan 9 väittämää ja niiden yleisyyttä omissa tuntemuksissaan ja ajatuksissaan.

Kyselyyn vastanneet olivat keskimäärin 49-vuotiaita (vaihteluväli 22-81 vuotta). Tiloilla oli keskimäärin 29 lehmää (vaihteluväli 4 - 220). Suurin osa (78 \%) vastaajien navetoista oli parsinavettoja. Suurimmalla osalla tiloista ( $83 \%$ ) ei työskennellyt perheen ulkopuolista työvoimaa.

\section{Tulokset}

Keskimäärin merkittävimmiksi arvioituja voimavaratekijöitä olivat "Lapsi tai lapset", "Oma perhe", "Eläinten terveys" ja "Oma puoliso tai kumppani". Maidontuottajien voimavarojen keskeisimmät lähteet ovat siis omassa lähipiirissä, mukaan lukien navetan terveet hoidokit. Keskimäärin vähiten merkittäviksi voimavaratekijöiksi jäivät "Luottamustehtävät", "Uskonto" ja "Viljelijöiden vertaistuki".

Kuormitustekijöistä merkityksellisimmiksi arvioitiin "EU:n maatalouspolitiikka", "Viljelijöiden kohtelu yhteiskunnassa ja mediassa", "Maatalousalan tulevaisuus" ja "Maatilan hallinto sisältäen tukihakemukset ja -tarkastukset". Vastaajia keskimäärin vähiten kuormittaviksi tekijöiksi jäivät "Oma tai muun henkilön alkoholin tai päihteiden käyttö", "Kumppani puuttuu" sekä "Suhteet vanhempiin tai appivanhempiin".

Kyselyyn sisältyi työuupumuksen arviointimittari MBI-GS. Vastaajista miltei puolella (46\%) ei ollut lainkaan työuupumusta, samoin miltei puolella (45\%) oli lievää työuupumusta ja $9 \%$ vastaajista poti vakavaa työuupumusta. Kun tuloksia verrataan Jari Hakasen (2005) 44-57-vuotiaista suomalaisista $(n=532)$ esittämiin tuloksiin, havaitaan, että maidontuottajat olivat tilastollisesti merkitsevästi useammin uupuneen väsyneitä ja kyynisiä kuin vertailuaineiston vastaajat keskimäärin. Ammatilliseen itsetuntoon liittyvien vastausten osalta aineistot eivät eroa toisistaan. Kahden tutkimuksen otokset kuitenkin erosivat toisistaan ainakin ikä- ja sukupuolirakenteeltaan.

Työn imu -mittarin tuloksia verrattiin Hakasen (2009) esittämään suomalaisista työntekijöistä $(\mathrm{n}=16335)$ koostuvaan aineistoon. Vastaajien keskimääräiset lukuarvot eivät eronneet toisistaan tilastollisesti merkitsevästi kahdessa aineistossa. Kun tarkasteltiin erikseen työn imun kolmea ulottuvuutta, lypsykarjatilallisten havaittiin kokevan tilastollisesti merkitsevästi enemmän työhön uppoutumista ja sille omistautumista kuin suomalaisista työntekijöistä koostuvassa verranneaineistossa. Vertailussa on jälleen otettava huomioon, että otokset erosivat toisistaan.

\section{Tulosten tarkastelu}

Tulokset vahvistavat jo aiemmista tutkimuksissa (Peltoniemi, 2005; Kallioniemi ym., 2009, Kallioniemi ym. 2011, Simola 2006) havaittuja tuloksia maatalousyrittäjien nykyisen toimintaympäristön kuormittavuudesta, mikä on aikaansaanut tutkimuksissakin esiin tulleita työhyvinvoinnin heikentymisestä kertovia oireita.

Työssä jaksaminen on yksi tärkeimpiä yrityksen tuotannontekijöitä, jolla voi olla kerrannaisvaikutuksia esimerkiksi yrityksen kehittämiseen, arjen toimintoihin, tapaturmien esiintymiseen ja tilalla hoidettavien eläinten hyvinvointiin. Nämä seikat lisäävät tulosten merkittävyyttä.

\section{Johtopäätökset}

Tulokset kertovat maidontuottajien positiivisesta työhön uppoutumisesta ja työlle omistautumisesta. Kuitenkin yli puolet $(54 \%)$ vastaajista poti jonkinasteista työuupumusta. Työuupumuksen mittari osoitti, että joka kymmenes $(9 \%)$ kyselyyn vastannut maidontuottaja sijoittui ryhmään "vakava työuupuminen". Nykyinen tilanne vaatii eri sidosryhmien yhteistyötä ja maatalousyrittäjien työhyvinvoinnin parissa toimivien valppautta tarttua epäkohtiin. 


\section{Kirjallisuus}

Enroth, A., Österman P. \& Teräväinen H. (toim.) 2003. Laajentavien tilojen haasteet. Tieto tuottamaan 104. Keuruu: ProAgria Maaseutukeskusten Liiton julkaisuja nro 998.

Hakanen, J. 2005. Työuupumuksesta työn imuun: työhyvinvointitutkimuksen ytimessä ja reunaalueilla. Työ ja ihminen, tutkimusraportti 27. Väitöskirja. Helsinki: Työterveyslaitos.

Hakanen J. 2009. Työn imun arviointimenetelmä. Helsinki: Työterveyslaitos.

Kalimo, R., Hakanen, J. \& Toppinen-Tanner, S. 2006. Maslachin yleinen työuupumuksen arviointimenetelmä MBI-GS. Helsinki: Työterveyslaitos. $56 \mathrm{~s}$.

Kallioniemi, M.K., Simola A.J.K., Kymäläinen H.-R., Vesala H.T. \& Louhelainen J.K. 2008. Stress among Finnish Farm Entrepreneurs. Annals of the Environmental and Agricultural Medicine, 15 (2), 243-249.

Kallioniemi M.K., Simola A.J.K., Kymäläinen H.-R., Vesala H.T. \& Louhelainen J.K., 2009. Mental symptoms among Finnish farm entrepreneurs. Annals of Agricultural and Environmental Medicine, 16 (1), 161-170.

Kallioniemi, M.K., Simola A., Kinnunen B. \& Kymäläinen H.-R. 2011. Stress in farm entrepreneurs. Teoksessa: Langan-Fox J. \& Cooper C.C. (toim.). Handbook of Stress in the Occupations. pp. 385-406. New horizons in management. Cheltenham, UK: Edward Elgar.

Martelin, T., Sainio P., Polvinen A., Pensola T., Koskinen S. ja Goud R. 2010. Työkyky eri väestöryhmissä. Teoksessa: Aromaa, A. \& Koskinen S. (toim.) Suomalaisten työ, työkyky ja terveys 2000luvun alkaessa. Raportti 11/2010. Terveyden ja hyvinvoinnin laitos. Helsinki: Yliopistopaino.

Melberg, K. 2003. Farming, Stress and Psychological Well-being: The Case of Norwegian Farm Spouses. Sociologia Ruralis, 43 (1), 56-76.

Parent-Thirion A., Macias E. F., Hurley J. \& Vermeylen G. 2007. Fourth European Working Conditions Survey. European Foundation for the Improvement of Living and Working Conditions. Luxembourg: Office for Official Publications of the European Communities.

Peltoniemi, A. 2005. Työllisten työkyky vuonna 2004. Työpoliittinen tutkimus Nro 273. Helsinki: Työministeriö.

Rikkonen, P. (2011), Esipuhe. s. 3. Teoksessa: Niemi, J. \& Ahlstedt J. (toim.), Suomen maatalous ja maaseutuelinkeinot 2011. Maa- ja elintarviketalouden tutkimuskeskus, Taloustutkimus. Julkaisuja 111.Vammala: Vammalan Kirjapaino Oy.

Saarni S. I., Saarni E.S., Saarni H. 2008. Quality of life, work ability, and self employment: a population survey of entrepreneurs, farmers, and salary earners. Occupational and Environmental Medicine, 65 (2), 98-103.

Simola, A. 2006. Henkinen hyvinvointi. Teoksessa: Rissanen, P. (toim.) Työterveys ja maatalous Suomessa vuonna 2004. Kuopio: Työterveyslaitos.

Väre, M. 2011. Suomalainen maatila, s. 14-17. Teoksessa: Niemi, J. \& Ahlstedt J (toim.), Suomen maatalous ja maaseutuelinkeinot 2011. Maa- ja elintarviketalouden tutkimuskeskus, Taloustutkimus, Julkaisuja 111.Vammala, Suomi: Vammalan Kirjapaino Oy. 